\title{
Assessment of Satisfaction and Environmental Preferences of Students
}

Navid Khaleghimoghaddam*

\begin{abstract}
This study seeks to explore the role of university campus quality in art students' satisfaction. Environmental satisfaction is one of the key criteria by which the extent of university educational quality may be determined. An educational environment of high quality campus conveys a sense of satisfaction with university environment that may be physical, social and symbolic. Satisfaction and dissatisfaction from the art students' point of view can be used as criteria for the campus planning, design and management to improve participation in environmental interaction and desire to more artistic performance. Data collection of the research was undertaken through a field study using photography, behavior monitoring and a questionnaire filled in by a sample of art students in Tabriz Islamic Art University. Descriptions and analysis of the results shows that the art students' satisfaction with their university campus environment is at a mid-level identity and legibility, access in the campus, sociability, livability, territoriality \& control are of the main physical-psychological factors
\end{abstract}

Keywords:Environmental quality, environmental preferences, environmental behavior, students' satisfaction, university campus.

*PhD.Student, Selcuk University, Faculty of Architecture, Konya, Turkey. E-mail: navid.khaleghi1363@gmail.com 
that may influence students' environmental satisfaction. According to the character of artistic creativity, contact with nature can have a positive influence on art students' environmental satisfaction.

\section{INTRODUCTION}

Tabriz Islamic Art University was established in 2000 for Islamic arts education and research around Iran and Islamic countries. The main campus of the university is located on the historic place of Khosravi Leather factory of Tabriz. The purpose of the university is to improve the situation of arts and artists in Iranians' life through educate students in various art fields, to do researches, to offer artistic as well as scientific services to different organizations and institutions, to establish cultural, artistic and educational relations, to exchange information with other educational organizations inside and outside the country and finally to provide educational facilities for knowledge seekers. Considering the problems facing contemporary university development in Iran, a better understanding of the students' environmental preferences and satisfaction has become necessary.

Figure 1. Location of the city of Tabriz and location of the Tabriz Islamic Art University (Technical office of Tabriz Islamic Art University, 2011)

Figure 2. Tabriz's historical leather industry factory's collection (Tabriz Islamic Art University) (Technical office of Tabriz Islamic Art University, 2011)
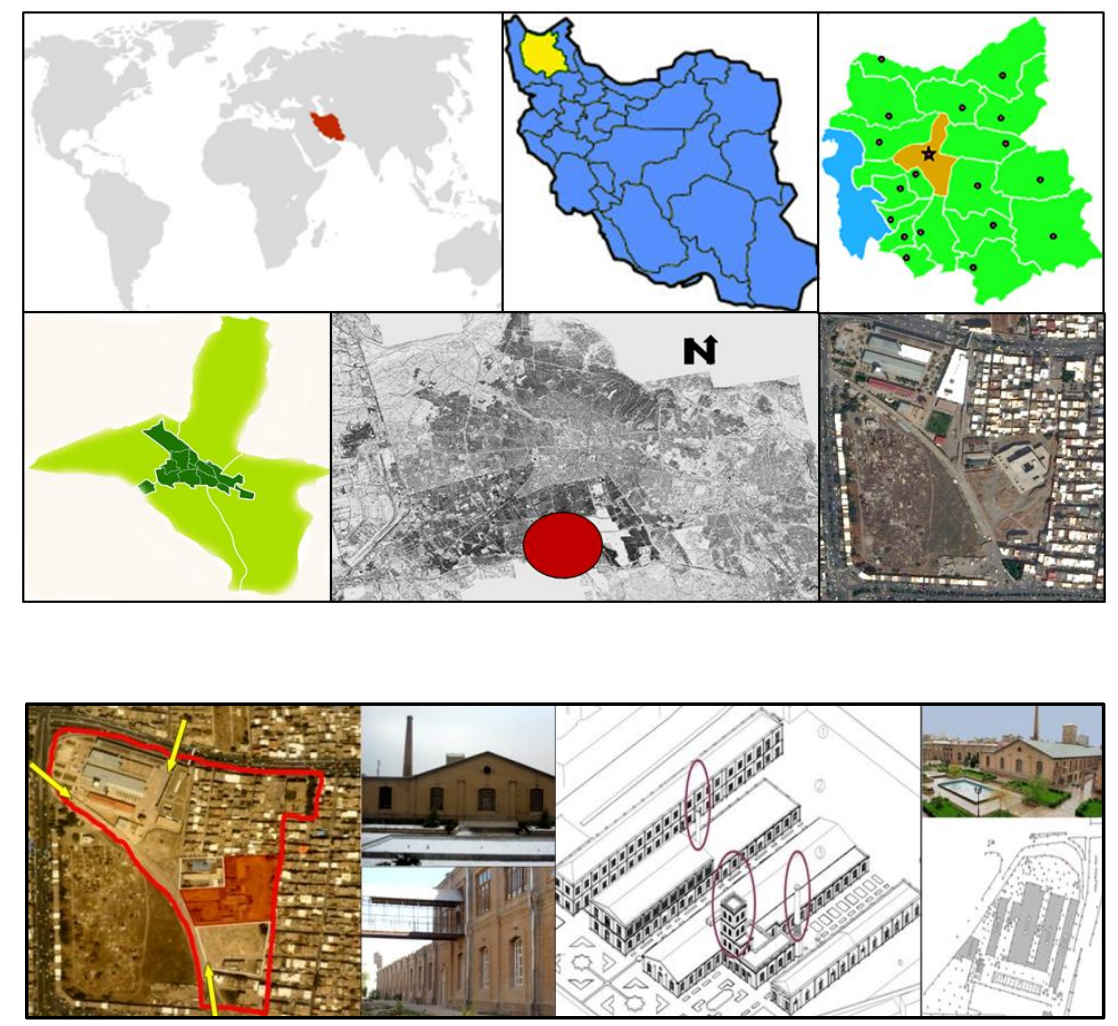

University like other forms of learning environments, like language, defines and facilitates the relationship between Student and his/her environment. The term university campus refers to an institutional space that is designed for use in the education and residence of college students (Isiaka \& Siong, 
2008) and includes the building and other physical elements found in the associated area (Shamsuddin et al., 2007). Existing university campuses require further development from time to time, based on the objective that must be achieved. The physical development planning of a campus can be considered to be successful if the project goals are achieved (Razak, Abdullah, Nor, Usman, \& Che-Ani, 2011). The buildings and grounds of campuses represent a rich physical record of changing design innovations and architectural norms. Architectural features are likely to become symbols for the university or college, or state or province (Bell, 2001). Art universities in Iran which are located in the well-known metropolises such as Tehran, Isfahan and Tabriz, have different design style on building architecture and campus landscape characteristics. It seems that art students have different environmental preferences and art universities needs to more sensitive campus design in relation to art students' desires, needs, preferences and satisfaction.

Therefore, this study is aimed to assess Tabriz Islamic Art University campus in identifying and analyzing the patterns of behavior from the perspective of providing satisfaction and environmental preferences in determine the quality of the campus and its development. History of modern design and development capabilities of wide-site university is dating back to the period after the Second World War (Gharavi, 2008). However, no research has been done on the satisfaction of students in campus. In a similar study, Ali Sharghi (2011) has worked on the effects of university campus landscapes on learning ability of students. In another similar study, urban planner and designer Raziyeh Rezazadeh (2002) in her research on the views of some streets in Tehran, asserts that, designer and users are experiencing and evaluating the urban place differently. In the research, which held on the rural places, it is related that the users' mental structures and preferances are affected by cultural specifications.
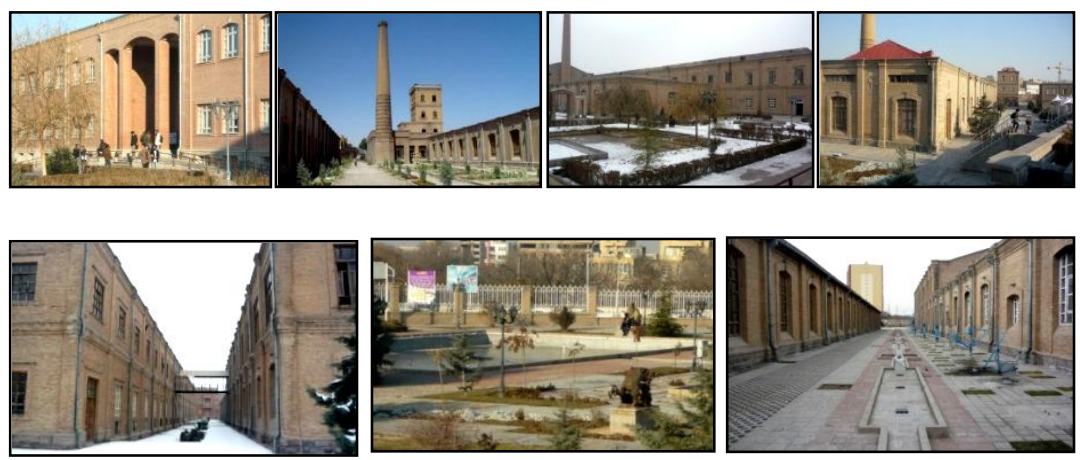

Figure 3. Applied arts faculty, sport complex, central library amphitheatre (Khaleghimoghaddam, 2016)

Figure 4. Library entrance students' park physical fitness facilities. (Khaleghimoghaddam, 2016) 


\section{RESEARCH METHOD}

As the main assumption, the university architecture and campus landscape can influence the students' educational perceptions and behaviors in relation to artistic creativity. Environmental assessment broadly encompasses efforts to describe environments or their components (Craik \& Feimer, 1987). Objective environmental quality indexes (EQI) Monitor quantitative environmental dimensions such as pollution levels, noise levels, property deterioration and other objective characteristics. Perceived Environmental Quality Index (PEQI) is designed to facilitate comparison of trends in the same environment over time, comparison of different environments at the same time and detection of aspects of the environment that observers use in assessing quality (Bell, 2001).

Students' satisfaction evaluation is an experiment of reality that depends on reasonable documentations such as field survey and filled checklists and questionnaires. Some researchers believe that planning and design evaluation is one of the best professions in problem solving. Due to the importance of art education and development of art universities in Iran, in this study we have tried to explore university campus design in relation to students' satisfaction evaluation. Students satisfaction can be determined by how well their university atmosphere meet their learning and educational expectations.

The present study uses the method of evaluation after implementating and investigating the environmental preferences and satisfactions, according to the evaluation criteria. Field data is documented in the face of buildings and open spaces. The evaluation of satisfaction and in the analysis of qualitative factors and preferences, the methods of giving questionaires and interviews were used. In the analysis of behaviors, the method of subtle viewing and recording the cognitive-environmental mapping were used. Maps were provided at different hours and motion diagrams with patterns of social behavior on the campus map were implemented. Reasons and objectives of presence in the different places are observed, assessed and analyzed.

\section{UNIVERSITY CAMPUS DESIGN}

Environmental evaluation is one of the most important tools to improve the quality of university environments. This article presents an environmental psychology approach to university campus evaluation. It is clear that in art education such as other fields of higher education, four main points should be noted as important and determinant factors: instructor's situation and conditions, student's artistic motivation and capabilities, 
educational content and educational space and facilities. Some characteristics such as educational technology development, existence of various facilities, materials for practical experiences and technical resources and equipments and new educational methods have important role in art universities. Art education such as the other fields of learning occurs in places where it is the designated purpose of the setting (school, seminars, practice fields, libraries, conservatories, museums, training grounds, etc.) and in places where learning According to an statement of Le Corbusier,1939, " The ... campus is a world in itself, a temporary paradise, a pleasant stage in life". Art universities are centers of creativity and novelty ideas in the public forms thateverybody can make a relationships with them. According to Dober(1963), there are three main parts of a campus, which include the buildings, outdoor spaces and supports elements such as utilities and circulation systems.

The effect of the design of university campus on the students' perceptions, cognitions, behaviors and affect within them has been of great interest to university quality researchers. Studies have indicated that the complexity of a university campus design can affect students' arousal and performances. Especially in art campuses, too many stimuli may distract students, create overload, or increase environmental fatigue. Some researchers believe that extremely simple campus environment may be boring and equally detrimental to performance (Sommer\& Olsen, 1990). However some others arguing that having more stimuli and opportunities for environmental exploration provide an enriched environment that facilitates learning. The next model shows the main relationship between university environmental affordances and students' satisfaction.

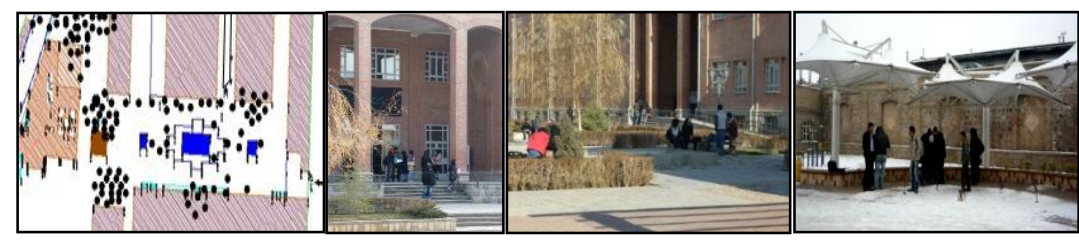

According to the importance of artistic creativity in art university curriculum, the students' environmental preferences and satisfaction can have an important role as a planning and design guideline to improve the university campus quality. Based on the idea that people prefer scenes that are engaging and involving rather than simple or boring, Kaplan \& Kaplan (2003) devised a framework to environmental preferences according to four elements: coherence, legibility, complexity and mystery. Coherence refers to the way that objects in a scene come together to form some sort of understandable context. Legibility refers to the level at which an individual is able to understand or
Figure 5 .Some campus open spaces as the students' environmental preferences (Khaleghimoghaddam, 2016) 
categorize the scene and the object within it. Complexity relates to the number and variety of elements within the scene. Mystery is the degree to which a scene contains hidden information or begs exploration (Kopec, 2006).

\section{STUDENTS' SATISFACTION EVALUATION}

The arrangement of space conveys information that can make environments more interesting and attractive, facilitate wayfindings, and enhance opportunities for exchange among individuals. People are attracted to environments that permit exploration and understanding and that offer nature with its restorative properties. Destinations that allow people to carry out meaningful actions, even purposes as simple as obtaining groceries, are also attractive. Thus, knowing what people prefer is important to each aspect and more likely to provide settings that encourage active engagement (Kaplan \& Kaplan, 2003)

Figure 6. Samples of activity zones and closed-end routes in the campus (Khaleghimoghaddam, 2016)
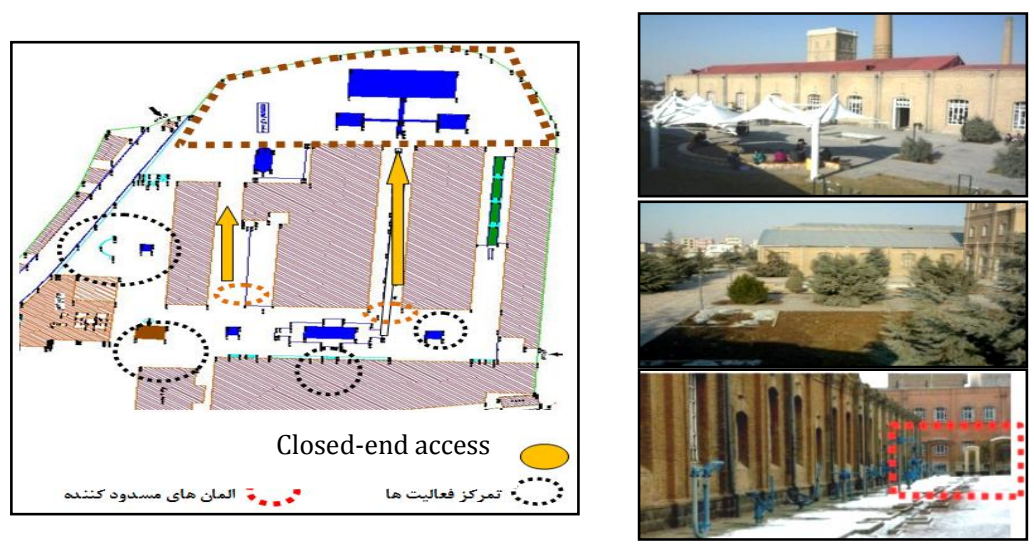

The students of TIAU are in Architecture (both BSc. And MSc.), Industrial Design, Carpet Studies. At present, TIAU is training students in $2 \mathrm{PhD}$ fields (Islamic Architecture and Islamic Urbanism), 6 MSc. \& MA fields in Architecture, Islamic Architecture, Islamic Art, Industrial Design, Urban Design, and Art Research, and 7 BSc. \&BA fields in Architecture \& Urbanization, Industrial Design, Islamic Art, Carpet Studies, Crafts, Multimedia, and Restoration. . Research is started to examine and recognize the qualities of places/buildings with a professional point of view.

The research finds a connection between users and designers by oberserving the users' responses to the designers' ideas. Public space is a multidimensional concept that affects social life (Rafiean and Khodaei, 2009). In the comprehensive approach, there are three criterias between man and the environment, when satisfaction is concerned (Daneshpour, 2004). The first field is "Formal Features" that includes components of the 
physical environment like perspective and views, scale, legibility, and permeability. The second field is "Activity Features" that includes components of noise, need, behavior, sociability and livability. The third field is "Meaning Features" like quality, definition, beauty, attachment and identity.

According to the results of the studies conducted by Baba and Austin (1989) as well as Bently Ian (2003), factors such as accessibility, continuity of passages, views, legibility, permeability, diversity and sociability in the utility and quality of space and user satisfaction are included. To evaluate students' preferences and satisfaction in campus, a survey was applied and a the following qualities related to campus open spaces environments were determined in parallel to the data obtained through the review of the literature:

- Art students' behaviors, needs, expectations

- Identity and legibility / Access in the campus

- Sociability / Livability / territoriality \& control

Questionnaires were given to 102 students and they were asked to answer the questions. After combining and gathering the qualitative datas they had decoupled, an analyzation is made and the results are matched with the hypothesis of the research and other findings. The students in the survey were mostly consisted of the 3rd grade bachelor degree students (70\%), and the others were master degree students (30\%). The average age of the participants were between 22-27 and the average response time was 6 minutes. The places where the surveys took place in the space between the educational buildings and in free space. Since most of the students are generally at the campus area in the middle of the day, the survey was conducted afternoon.

Table 1. The sample suestions related to the questionnaire (khaleghimoghaddam, 2016)

\begin{tabular}{|l|l|l|}
\hline \multicolumn{1}{|c|}{ Formal Features } & \multicolumn{1}{|c|}{ Activity Features } & \multicolumn{1}{|c|}{ Meaning Features } \\
\hline $\begin{array}{l}\text { My university in terms of } \\
\text { form and symbol is legible. }\end{array}$ & $\begin{array}{l}\text { The landscape of my } \\
\text { university has a sense of } \\
\text { novelty and freshness. }\end{array}$ & $\begin{array}{l}\text { I am fascinated by the } \\
\text { beauty and fascination of } \\
\text { my university places. }\end{array}$ \\
\hline $\begin{array}{l}\text { My university has a useful } \\
\text { space accessibility. }\end{array}$ & $\begin{array}{l}\text { Ifeel safe while walking } \\
\text { and sitting in my } \\
\text { university. }\end{array}$ & $\begin{array}{l}\text { In terms of memories and a } \\
\text { sense of attachment, my } \\
\text { university has a unique } \\
\text { identity. }\end{array}$ \\
\hline $\begin{array}{l}\text { My university has good } \\
\text { and memorable view and } \\
\text { prospect. }\end{array}$ & $\begin{array}{l}\text { Designed spaces in my } \\
\text { university are sociable. } \\
\text { allows to meet and } \\
\text { interaction. }\end{array}$ & $\begin{array}{l}\text { In most cases, The spases of } \\
\text { my university are defined. }\end{array}$ \\
\hline $\begin{array}{l}\text { In terms of closeness, my } \\
\text { university has good scale } \\
\text { and feel safe. }\end{array}$ & $\begin{array}{l}\text { The sound of water and } \\
\text { plants makes me happy. }\end{array}$ & $\begin{array}{l}\text { I am proud of my university } \\
\text { and I love it. }\end{array}$ \\
\hline
\end{tabular}


During the field study, investigations were carried out in order to check whether campus spaces are responsive environments for the art students' desires, needs and expectations. The questionnaire was a set of some open-ended questions about students' experiences and environmental preferences and satisfaction in different open spaces of the university campus. In the table below, there is a citation about the results of free comments committed by the participants related to the assessment of satisfaction and environmental preferences of students.

Table 2. Assessment of satisfaction and environmental preferences of students (Khaleghimoghaddam, 2016)

\begin{tabular}{|c|c|c|}
\hline Svaluation Criteria & $\begin{array}{c}\text { Central } \\
\text { courtyard \& } \\
\text { Service spaces }\end{array}$ & $\begin{array}{c}\text { Backyard \& } \\
\text { Ancillary } \\
\text { spaces }\end{array}$ \\
\hline Permeability & $68 \%$ & $8 \%$ \\
\hline Accessibility & $63 \%$ & $12 \%$ \\
\hline Legibility & $69 \%$ & $19 \%$ \\
\hline Sociability & $64 \%$ & $2 \%$ \\
\hline View and prospect & $71 \%$ & $14 \%$ \\
\hline Livability / Novelty & $67 \%$ & $6 \%$ \\
\hline
\end{tabular}

\section{CONCLUSION}

The findings of the literature research and field studies showed that students 'environmental satisfaction can be divided into three main parts: functional-environmental, structuralinfrastructural and spatial-aesthetical factors. For creating more artistic atmosphere in Art University campuses more interaction should be manage between students, staff and the university campus environment. Environmental exploration, meaningful actions and restoration are some of the conceptual factors which can help to planning and designing more responsive campus environments meeting art students' satisfaction. The article argues the conceptual pattern of reasonable person model (Kaplan \& Kaplan, 2003). In addition to environmental factors that are based on the way the space is organized, this article also highlights the particular role played by natural environments. In the university campus, it is the content-the trees, water, vegetation-that has strong positive impacts on students' preferences and satisfaction. Improving Moreover, the 
documentation procedure of different institutional requirements of art faculties can be used as a guide to environmental design of the campus. More studies needs to explore the different environmental characteristics for satisfaction in relation to different arts education.
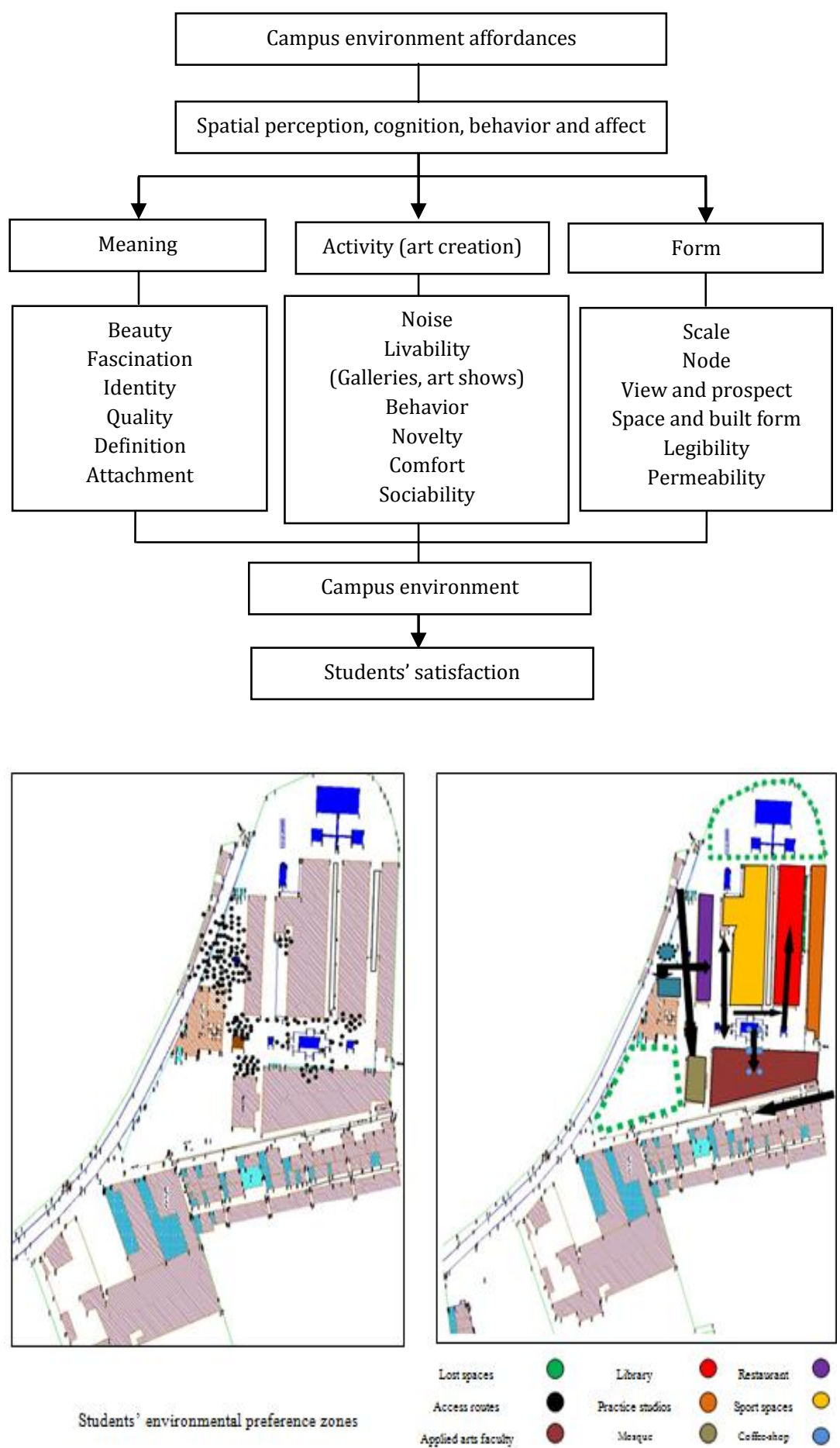

Satisfaction and dissatisfaction from the art students' point of view can be used as criteria for the campus planning, design and management to improve participation in environmental
Diagram 1. The model of students' environmental satisfaction in art university campus

(Khaleghimoghaddam, 2016)

Figure 8. The historic well- leather factory of Tabrizhas been revitalized as the main campus of TIAU from 2000 , yet is one urban landmark in Tabriz historic urban context. (Khaleghimoghaddam, 2016) 
interaction and desire to more artistic performance. Data collection of the research was undertaken through a field study using photography, behavior monitoring and a questionnaire filled in by a sample of art students in Tabriz Islamic Art University. According to table 2 descriptions and analysis of the results shows that the art students' satisfaction with their university campus environment is at a intermediate level. This finding means that the university campus needs to develop and complete with the other faculties around it and many open spaces in the campus needs to new responsive environmental design in relation to students needs and preferences. For example the university in the last 3 years has bought some of the neighborhood derelict industrialized factories around the university and has started to develop the university campus. Legibility, access in the campus, sociability, livability, territoriality \& control are of the main physical-psychological factors that may influence students' environmental satisfaction. The finding of the presented pictures in the article shows that the preferred campus spaces always are designed with nature contact. According to the character of artistic creativity, contact with nature can have a positive influence on art students' environmental satisfaction. In the next pictures are presenting some of the main university community open spaces.

Figure 9. The university campus has been a leather factory 30 years ago and the students mension the important historical industrialized identity of the campus.

(Khaleghimoghaddam, 2016)

Figure 10. The most livable spaces of the campus the access routes. (Khaleghimoghaddam, 2016)
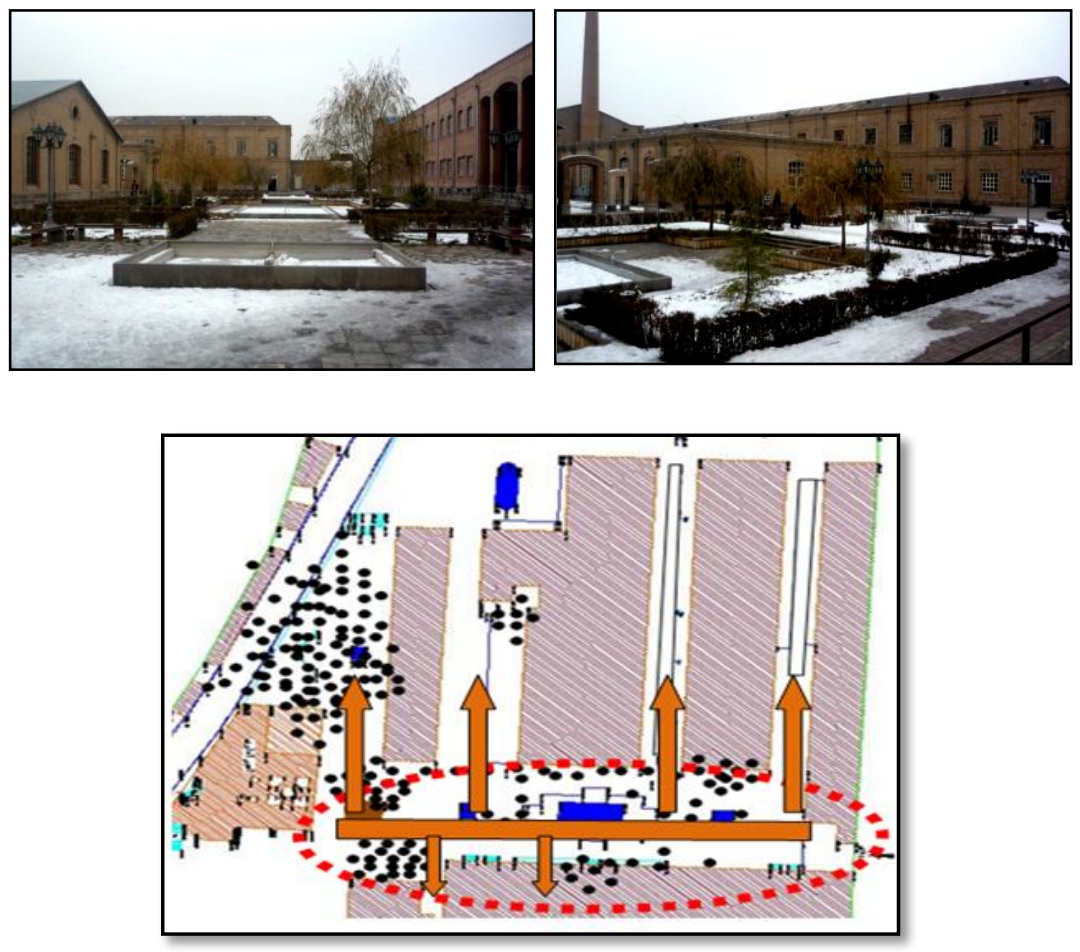


\section{Acknowledgement}

This article is adapted from the author's master thesis entitled "Development Plan of the Campus of Tabriz Islamic Art University" that is completed in March 2013 under the guidance of the Dr. Mohammad Bagheri at Tabriz Islamic Art University of Iran.

\section{REFERENCES}

Baba, Y., Austin D. M., (1989). Neighborhood environmental satisfaction: Victimization and social participation as determinants of perceived neighborhood safety, Environment and Behaviour, Vol.21, No.6.

Bell, P. A., Greene, T.C., Fisher, J. D. \& Baum, A. (2001). Environmental Psychology. Journal of Environment and Behavior(The Soft Classroom).

Craik, K., Feimer, N. R. (1987). Environmental assessment. In D. Stokols \& Altman (Eds.), Handbook of environmental psychology (pp 891-918). NewYork: Wiley.

Daneshpoor, A., (2004). Recognition of The Identity of The Manmade Environment, Journal of Bagh-I-Nzar, No.1 Tehran. Iran.

Dober, R., (1963). Cmpus Planning. New York: Reinhold Publishing Co.

Gharavi, M., (2008). Qualitative Evaluation of University ofTehran. Journal of Fine Arts, University of Tehran, No(35), Autumn, pp. 75-84.

Ian, B., Smith, G., Mcglynn, S., Murrain, P., Alocock, P., (2003). Responsive Environments., Routledge; Revised ed.

Isiaka, A., \& Siong, H. C. (2008). Developing Sustainable Index For University Campus. Paper presented at the EASTS International Symposium on Sustainable Transportation incorporating Malaysian Universities Transport Research Forum Conference.

Kaplan, S., \& Kaplan, R. (2003). Health, supportive environments, and the reasonable person model. American Journal of Public Health, 93(9), 1484-1489.

Kopec, D. (2006). Environmental Psychology for design.

Rafieian M., Khodaei Z., (2009). Evaluation Criteria and Standards Affecting The Satisfaction of Citizens in Urban Public Spaces, Journal of Rahbord, No.53. pp. 227-248.

Razak, M. Z. A., Abdullah, N. A. G., Nor, M. F. I. M., Usman, I. M., \& Che-Ani, A. I. (2011). Toward a sustainable campus: Comparison of the physical development planning of research university campuses in Malaysia. Journal of Sustainable Development, 4(4), 210.

Rezazadeh, R., (2002). New urban design strategies for pedestrian safety in Tehran, $16^{\text {th }}$ international conference on safe communities, Iran.

Shamsuddin, S., Sulaiman, A. B., Lamit, H., Omar, R., Aziz, N. A., \& Noor, M. M. (2007). Kriteria Reka Bentuk Persekitaran 
Kampus Yang Kondusif Bagi Institusi Pengajian Tinggi Di Malaysia. University Teknologi Malaysia (2007 (b).

Sharghi, A., (2011). Effects of University Campus Landscapes on Learning Quality of Students (Functional Analysis of Attention Restoration Theory), Journal of Bagh-e Nazar, Vol.8/No.18. pp. 25-36. Tehran. Iran.

Sommer, R., Olsen, H., (1980). The soft classroom. Journal of Environment and Behavior,12,16.

Stokols, D., \& Altman, I. (1987). Handbook of environmental psychology (Vol. 2): Wiley.

Strategic plan and Development Plan of Tabriz Islamic Art University,. (2011). Technical Office of Tabriz Islamic Art University., unpublished technical report, central library of the university.Tabriz, Iran.

\section{Resume}

Navid Khaleghimighaddam, is a PhD Student in Architecture at Selcuk University in Konya, Turkey. He is also a lecturer in selcuk university in Turkey as well as in several universities in Iran. He is working on Environmental Psychologhy, Cognitive Psychologhy and Environmental Perception for his Doctorial thesis. He has been writting several articles on environmental psychologhy since 6 years ago in his academic career. He is interested in to work on Environmental Psychology, Perceptual-Behavioral characteristic of Place in (such as Learning Environments, Open public spaces, Residential Environments and Healing Environments), Creativity and Environmental Characteristics and Architectural Education. He has done several research projects for government organizations in Iran. He admissioned of excellent student with no examination for M.A Degree, Under Ministry of Science, Research and Technology \& State Education Evaluation Organization and he Obtained the First Rank in the field of Architecture In the 4 semester of Bachelor, at University of Yazd in Iran. 